\title{
Egy skót bírói döntés jogszociológiai elemzése
}

\author{
David Hume - házasságon belüli eröszakos közösülés - skót jog - \\ common law - nők helyzete
}

A jogszociológia, illetve a szociológiai jogelmélet - minden „híreszteléssel” ellentétben - nem csupán puszta teoretizálás. Sokkal inkább konkrét elemzések elvégzésére képes diszciplína, mely alkalmas egyes jogágak, jogintézmények, mi több jogszabályok megalkotásának, továbbá a jogalkalmazás és a jogi normák közti összhang vagy diszkrepancia társadalmi okaira rávilágítani. Vagy éppenséggel hogyan és miért, milyen szociális okokra visszavezethetően torzítja a jog puszta nyelvtani értelmezését a jogalkalmazás, akár az egész jogrendszerre, akár egy-egy jogágra, vagy éppen egy-egy jogi rendelkezésre tekintünk. $S$ természetesen fordítva is igaz a kérdés: egy jogág, jogi rendelkezés etc. hogyan, milyen módon, továbbá milyen mértékben hat az adott társadalomra.

Az esettanulmányok pedig éppen olyanok, mint a szociológiában általában megszokott esettanulmányok, csak éppen a jogra vetítve; vagyis egy meghatározott jogszabály, vagy egy jogág, és az arra vonatkoztatható jogeset, illetve annak konkrét alkalmazása során levezethető az a társadalmi háttér, amely az adott esetet végső soron indukálta. $S$ mindez persze sokkal többre is rámutat, nemcsak a jog és a társadalom összefüggéseire, hanem a jogon belüli kapcsolódási pontokra, továbbá - $s$ talán ez a legfontosabb - a társadalom „mélykérdéseinek” feltárására; mindezt pedig egy látszólag egyszerū jogeseten keresztül.

Jelen esetben a skót bírói eljárásban a házasságon belüli eröszakos közösülés (marital rape) esettanulmányának elemzése „kerül terítékre”. Egész pontosan az erőszakos közösülés tényállásának kérdése, amennyiben ez házassági kapcsolaton/életközösségen belül történik. S miért pont Skócia? S miért pont a fenti tényállás? A kérdést már csak azért is érdemes feltenni, mert minden bizonnyal hasonló esetek más országokban is történnek. Nos, ennek több oka van, nevezetesen:

1. Skócia az Egyesült Királyság része, $s$ bár jogrendszere sokkal inkább kontinentális jellegü, nehéz lenne tagadni, hogy a common law hatása „megérintette.”

2. A tényállás megítélésének "töretlen bírói gyakorlata" - szinte egy csapásra 1989-ben változott meg, anélkül hogy a jogalkotó ebbe bármilyen formában beavatkozott volna.

* Dr. Nagy Zsolt tanszékvezető egyetemi docens, Szegedi Tudományegyetem Állam- és Jogtudományi Kar Jogbölcseleti és Jogszociológiai Tanszék, nagyzs@juris.u-szeged.hu. 
3. S ez már csupán egy kuriózum: egy kontinentális jogrendszerü társadalomban a jogalkalmazó változtatta meg a tényállás megítélését (ti. házasságon belül nem történhet eröszakos közösülés), holott a bírói szervek erre talán nem is lehettek volna jogosultak (preator jus facere non potest). Vagyis érdemes egy pillantást vetni arra a jogrendszerre, jogalkalmazásra és általában a társadalomra, mely ezt ebben a formában megtette, már csak azért is, mert esetleg más társadalmakra nézve is tanulságos lehet.

1989-ben született Skóciában egy bírósági döntés az úgynevezett Stallard ügyben, mely esetben mind az elsőfokú, mind a fellebbviteli bíróság Baron Hume ${ }^{1}$ autoritására hivatkozva ítélte meg a házassági életközösségen belül megtörtént erőszakos közösülést. ${ }^{2} \mathrm{Az}$ esetben hozott ítélet érdekessége, hogy korábban ilyen döntést nem hoztak, vagyis házasságon belül "nem lehetett” erőszakos közösülést véghezvinni. Pontosabban véghez lehetett vinni, csak a bíróság a férjnek az eljárás alól úgynevezett „immunitást” biztosított, vagyis nem lehetett az egyébként létező bűncselekmény tekintetében az elkövetőt bírói eljárás alá vonni. Minden más esetben természetesen az erőszakos közösülés elkövetője törvényes eljárás szerint megítéltetett, de amennyiben az elkövető és a sértett házastársak voltak, a skót jog szerint az eljárást le sem folytathatták. A dolog manapság meglehetősen „furcsának” tünik, hiszen napjaink gondolkodásmódja, társadalmi szemlélete szerint a döntésnek evidensnek kellett volna lennie, de a dolog valójában komplikáltabb. (S ne felejtsük, hogy a Büntető Törvénykönyv szerint Magyarországon is hosszú időn keresztül csak a házassági életközösségen kívüli erőszakos közösülést büntették. $)^{3}$ Vagyis egyáltalán nem evidens kérdésröl van szó, hiszen a jogalkotás és a jogalkalmazás szerte Európában nagyon hosszú ideig máshogy "látta” a fenti tényállást. Ezért talán $-\mathrm{s}$ éppen ez lenne a jogszociológia egyik feladata - nézzük meg egy kicsit közelebbről, illetve távolabbról a problémakört, pontosabban nézzünk rá a döntés jogi és társadalmi okaira.

\section{Jogtörténeti elözmények}

Az köztudott, hogy 1707-ben a skót és az angol uralkodói reálunió nem járt együtt az egyházi és a világi jogi edukáció és az adminisztratív rendszer azonosulásával. A büntetőjog tekintetében pedig ez különösen igaznak mondható. S hogy miért?

1 Hume, Baron David: Commentaries on the Law of Scotland Respecting the Description and Punishment of Crimes. Two Volumes. Edinburgh: Printed for Bell \& Bradfute... And for E. Balfour, 1797. With: Supplemental Notes. Edinburgh: Printed for Bell and Bradfute, 1814. Three volumes altogether. Baron David Hume a skót jog professzora volt Edinburgh Egyetemének a skót büntetö- és magánjog kiváló ismerője, később a Baron of Exchecquer funkciójának viselöje. (Mellesleg rokona volt David Hume-nak, a filozófusnak.) Napjainkban a használatos verzió: Hume, David, Cameron, John, Walker, David Maxwell, BelL, Benjamin Robert: Commentaries on the law of Scotland, respecting crimes. Law Society of Scotland. Edinburgh. 1986.

2 Stallard v. Her Majesty's Advocate (1989) SLT 469; (1989) SCCR 248.

3 Az 1999. elötti magyar Büntetö Törvénykönyv szerint „Aki nöt házassági életközösségen kívül erőszakkal vagy élet, illetve testi épség elleni közvetlen fenyegetéssel közösülésre kényszerít ..." 1978. évi IV. törvény A büntetö törvénykönyvröl, 197. §. 
Talán ez a legérdekesebb, ugyanakkor a legbonyolultabb, és leginkább a régmúltba visszanyúló kérdés, melyre a válasz Skócia és Anglia viszonyában kereshető. Ez a viszony a mai napig is „ambivalensnek” mondható, hiszen a Brit-szigetek joga - ebböl a szempontból - önmagában is egy összehasonlító jogi unikumnak tekinthetö. Történeti szempontból az 1604-es perszonáluniótól érdemes kezdeni az események bemutatását: VI. (I.) Jakab királynak éppúgy szembe kellett néznie a jogi diverzitással, mint elödeinek Angliában vagy Walesben; csakhogy ez a jogi különbözőség nem az egyes kisebb területek eltérő szokásaiban rejlett, hanem az Anglia és Skócia közötti teljesen eltérő jogszabályokban és jogi kultúrában (gondoljunk csak a Magyar Királyságból származó és a skót államalapítást segítő Skóciai Szent Margitra). Kisvártatva a király az alsóháznak - bár sikertelenül - már javasolta is, hogy egyféle - tudós jogászok munkáinak segítsége melletti - kodifikációval egységesíteni lehetne a két ország jogrendszerét. ${ }^{4} A$ helyzet azonban épp a király akarata ellenére alakult: a XVII. századra a skót jogrendszer egyre inkább - különösen a családi és a polgári jog tekintetében - „teljes és zárt struktúrává” alakult, aminek - $\mathrm{s}$ mellesleg a skót jogászságnak is - egyfajta kézjegyéül szolgált Sir James Dalrymple of Stair 1681-es Institúciói (Institutions); s ezt a helyzetet a történelmi viharok sem tudták megváltoztatni. ${ }^{5} \mathrm{~S}$ ami még érdekesebb, hogy az 1707-ben létrehozott Nagy-Britannia és Észak-Írország mint Egyesült Királyság dokumentumának 18. és 19. szakaszai kifejezetten rendelkeztek arról, hogy a skót magánjog nem lehet az egyesülés tárgya. A jogi helyzet azonban csak most kezdett igazán érdekessé válni. Történelmi háttérként csak annyit érdemes megemlíteni, hogy ettől kezdve egyetlen brit parlament létezett (The Parliament of Great Britain), s felsőházának (House of Lords) tagjai között ott ült tizenhat skót fönemes is. ${ }^{6} \mathrm{~A}$ jog szempontjából azonban az az érdekesebb, hogy ez a felsőház az angol felsőbíróságok fölött fellebbviteli funkciót látott el, de a skót bíróságok fölötti hasonló funkció nem volt ennyire világos és nyilvánvaló. Ám az igazi kérdés csak most merül fel: a skót jogásztársadalom miért nem ragaszkodott az egyesülési szerződés szövegéhez, tehát egy külön skót jogot alkal-

${ }^{4}$ Az egységesítésnek természetesen politikai okai voltak: a perszonálunióból a király a két ország között „Szorosabb kapcsolatot” szeretett volna létrehozni; ezen kívül egy hosszabb távú unióhoz mindenképpen szükség volt a két jogrendszer közelítésére. Nyilvánvalóan ez mindkét részröl ellenállást váltott ki: a skót bizottság részvételének hiányával folyamatosan bojkottálta a törekvést, továbbá - noha néhányan a korábbi walesi példához hasonlították a kialakult helyzetet - sok angol politikus értekezett arról, hogy az ilyen jogegységesítés nemcsak hogy teljességgel fölösleges, de rendkívül veszélyes is. 1608-ra pedig teljesen világossá vált, hogy VI. (I.) Jakab jogegységesítési törekvése sikertelen. VAN DEN BERG, Peter: Lawyers as Political Entrepreneurs? A Historical Perspective on the Contribution of Lawyers to Legal Integration in Europe. 170. http://rechten.eldoc.ub.rug.nl/FILES/root/Algemeen/Recht10/2005/entrepreneurs/Lawyers. pdf (2014. 08. 10.); továbbá Levack, Brian P.: The proposed union of English law and Scots law in the seventeenth century. Juridical Review, 20. évf. 1975., 97-115, 102-105.

5 A skótoknak Oliver Cromwelltöl elszenvedett 1650-es, majd az 1664-es és az 1670-es vereségeik. Levack: i. m., $112-114$.

6 Mely parlamentben - föleg figyelembe véve és összehasonlitva a walesi képviselök számát, illetve Wales területének nagyságát, és népességét - egyértelmüen kimutatható, hogy a skót törvényhozási képviselet alulreprezentáltnak volt mondható. (A Képviselőházban 45 skót tag ült.) Vö.: CRUICKSHANKs, Lauchlin Alexander: The Act of Union: Death or Reprieve for the Highlands? A Study of Socio-Economic Impact of the Union on the Highlands of Scotland, 1707-1745. Wesleyan University, The Honors College, Middletown, Connecticut, April 2008, 53. 
mazó skót felsőbírósághoz (az persze természetesnek tủnik, hogy angol kollégáik inkább az egységesítés mellett voltak). Mellesleg az nyilvánvaló, hogy az egyesülési szerződést kidolgozó harminc skót bizottsági tag (köztük kilenc neves jogász) figyelemmel volt erre a kérdésre, mi több, „fö félelmük” az volt, hogy „a skót jog lassan, de biztosan angol joggá válik". ${ }^{7}$ A válasz a lehetőségek behatárolt voltában rejlik, vagyis a skót bizottság tagjai féltek az alternatívától: egy új skót fellebbviteli bíróság egyértelmüen a korona alatt müködött volna, tehát a korona befolyása alatt is állt volna. Ezért úgy gondolták, hogy - már egyszerüen csak a fizikai távolság miatt is - a Lordok Háza kevés skóciai üggyel fog foglalkozni, következésképpen kevésbé valószínủ a skót jog erodálódása. Talán egy kissé leegyszerüsítve, de kimondható, hogy a skótok két tényezőben is tévedtek: egyfelöl sokkal közelebb került a két jogrendszer egymáshoz, mint ahogy arra számítottak, másfelöl pedig ez a közeledés és/vagy a megmaradt távolság nem az igazságszolgáltatás szervezeti kérdéseiben rejlett. Ha az első kérdésre tekintünk: a Lordok Háza sok esetben mind skót, mind az angol jogi tradíciókra alapozott döntéseket, noha az is igaz, hogy sok skóciai eredetú esetben a common law befolyása erősebbnek tủnt. ${ }^{8}$ Ám a második felvetésben rejlik az igazi válasz: mire az 1700-as évek elejére kialakult a megfelelő közjogi-politikai helyzet, a skót jogászság már egy integrált rendszert képezett, a jog már egy kidolgozott, szofisztikált rendszerré vált, egy olyan struktúrává alakult, mely immáron eredményesen állhatott ellen az angol jog befolyásának. A XVIII. század - mikor a skót jogi intézmények, mint például a Court of Session és a Faculty of Advocats, melyek a „skót nemzet” közjogi és politikai fórumaivá váltak és müködtek - volt igazából a skót jog „aranykora”, mivel ekkor tudott igazán együtt fejlődni a kontinentális Európa jus commune-jével. ${ }^{9}$ (Az 1999-ben megtörtént Skót Parlament felállítása pedig feltehetően ezt tovább erősítette és erősíti.)

Mindezek alapján ki lehet mondani, hogy az angol jog bizonyos esetekben sikeresen befolyásolta a számára idegen jog fejlödését, illetve tökéletesen involválódott a jogrendszerbe, más esetben azonban nem. Noha ez önmagában még evidens, az összefüggést inkább az idegen jogrendszer minőségében, nevezetesen relatív „gyengeségében”, illetve „erősségében” kell keresni. Ugyanis amikor az angol jog és jogászság a helyi szokásokkal, írásba nem foglalt szabályok bonyolult szövedékével találta szemben magát, illetve olyan jogászsággal, amely nem integrálódott és nem képviselt egységes szabályrendszert, akkor ez a rendszer könnyen adaptálta - ráadásul sok esetben, legalábbis bizonyos idő után -, talán egyfajta "megváltásnak” tekintette az idegen jogot. ${ }^{10}$ Azonban ha ezek a szokások egységesebbek voltak,

7 Maclean, A. Jan: The 1707 Union: Scots law and the House of Lords. Journal of Legal History, vol. 4. 1984/3, 50, 51, 67. Az eredeti szöveg talán jobban adja vissza az említett „félelmet”: „danger of Scots law becoming English law by the secret and certain operation of time". A skót-angol egyesülés politikai, gazdasági, társadalmi és jogi relevanciájáról lásd CRUICKSHANKS, i. m.

8 Ennek egyik eklatáns példája volt a Donoghue v. Stevenson ügy, 1932. All English Law Reports, 1-32. Ez minden kétséget kizáróan egy „skót ügy” volt, de a döntést igen jelentékenyen befolyásolta az angol jog. VAN DER BERG: i. m., 172.

9 Uo.

10 1283-ra Walest elfoglalták, és angol uralom alá került; természetesen az „új urak” ismét szemben találták magukat - csakúgy, mint Hastings után - a jogi diverzitással, amire gyógyírként a törvényi jogot próbálták 
írásba voltak foglalva, megtalálható volt egy integrálódott jogásztársadalom, mi több, kimunkált jogkönyvek álltak rendelkezésre, neves szerzőkkel, akik autoritásként és iránymutatásként szolgáltak a szabályok között, az angol jog már kevésbé volt eredményes; elérhetett egyfajta együttélést és együttmüködést, de semmiképpen nem válhatott mindent elsöprő, uralkodó tényezővé.

\section{A skót (büntető-) jogi gondolkodás és annak változása}

Kifejezetten a büntetőjogra rátérve: a fenti történeti fejtegetésekkel összefüggésben immáron 200 éve folyik - érvek és ellenérvek ütköztetésével - a vita, hogy vajon a skót felsőbíróságnak (High Court) van-e joga arra, hogy bizonyos cselekményeket, melyek „,helytelenek”, „immorálisak” vagy „bünös természetüek”, büncselekménynek minősítsen. ${ }^{11}$ Végső soron a vita alapja Baron Hume műve, nevezetesen Skócia jogának kommentárjai, különös tekintettel a büncselekményekre (Commentaries on the Law of Scotland Respecting Crimes). A kommentárok szerint a skót jogban inherens hatalom (inherent power) rejlik, miszerint minden olyan cselekedetet, melynek kriminális természete (criminal nature) van, büncselekménynek nyilváníthat, és innentöl kezdve pedig már csupán értelmezés kérdése a megoldás, mely értelmezés viszont többféle lehet. Az említett vita az úgynevezett Bernard Greenhuff ügyben csúcsosodott ki. ${ }^{12}$ Mindenesetre a későbbi ügyek alapján háromféle bírósági „viselkedést" lehetett definiálni. 1. A bíróság kifejezetten elutasította, hogy használja az említett kriminalizálási hatalmat. 2. Amikor a bíróságok ugyan elismerték az erre vonatkozó jogukat, ám csak kivételes esetekben éltek vele. 3. Amikor a bírák ugyan semmilyen jelét nem adják, hogy használják ezt a lehetőséget, de mégis minden kétségen felül élnek vele. ${ }^{13}$

Ugyanakkor az akadémiai ortodoxia a következőkben foglalható össze: a fenti bírói hatalom a legalitás ellenében hat, miszerint nincs büntetés törvény, vagyis elözetesen kihirdetett (érvényes) jogi rendelkezés nélkül. Egy ilyen hatalom létezése törvényrontó (desuetudo) hatású, és semmiképpen sem lehet megtürni egy modern

alkalmazni, ám kevés sikerrel. Wales elfoglalása inspirálta az angol esetjog kodifikációjának korai kísérletét is, illetve az adott rá okot; ugyanakkor a helyi szokások „elég hangosak” voltak ahhoz, hogy az angol törvények egyáltalán nem, vagy csak részben érvényesülhettek. Sőt mi több, a westminsteri bíróság tartózkodott az újonnan szerzett területek „,ölött” döntéseket hozni, vagyis a helyi szokások - egy idöre legalábbis - tovább virágoztak. Ám itt is bekövetkezett az, ami Angliában: a helyi, íratlan szokások helyébe - fokozatosan - a királyi bíróságok gyakorlata és az ott tevékenykedő jogászok döntéseinek rendszere került, és 1536-ra formálisan is - a helyi szokásjog gyengeségének köszönhetően - az egységes királyi jog lett uralkodó. Uo., 168.

11 „Jogunk zsenialitása éppen az angol joggal ellenkező elvekben rejlik; nevezetesen a büntetöbíróságok fel vannak hatalmazva, hogy minden pozitív szabály nélkül büntetéssel sújthassanak egy büncselekményt." WRIGHT, Rachel: Justiciary Court. 1809. In: BURNETT, John: A Treatise on Various Branches of the Criminal Law of Scotland. Edinburgh. Arch Constable and Co, 1811, XXIX.

12 GreehufF, Bernard (1838) 2. Swin. 128. 236. In: Gordon, Gerald Henry: The Criminal Law of Scotland. Edinburgh, W. Green and Son, 2nd Edition, 1978, 23-43.

13 FARMER, Lindsay: „The Genius of our Law..." Criminal Law and the Scottish Legal Tradition. The Modern Law Review. Vol. 55, 1992/1, 25. 
jogrendszerben. Ám a common law rendszer a meglévő elvek alapján is lehetővé teszi a "fejlődést”; sok esetben a flexibilitásra, az „eredendő értelemre”, s a józan észre, mint a skót jog sajátosságára és nem pedig a legalitás elvével való konfliktusra kell gondolni. Vagyis végső soron inkább az igazságszolgáltatás ez irányú hatalmának mérséklését kérik, de leginkább használatának elkerülését, legalábbis az ellentmondásos ügyekben. De végső soron az akadémiai szféra és a gyakorlati élet szereplői közti (nem e két szféra, hanem inkább az egyes szereplők álláspontjai közti) vitában a jog kreatív hatalma és a joguralom (rule of law) dichotómiája jelenik meg, vagyis nem egy-egy eljárásban való jogkérdés megoldásának mikéntje körvonalazódik, hanem egyszerüen az, hogy ugyanazon a jogrendszeren belül mit is jelent a legalitás (legality). ${ }^{14}$ Tehát a vita a felsőbíróság deklaratív hatalma körül folyik: nevezetesen, hogy a bírói döntéseknek konstitutív vagy deklaratív ereje van-e valójában. (A konstitutív erő azt jelenti, hogy minden egyes döntésükkel a bírák ténylegesen jogot hoznak létre, a deklaratív erő pedig azt, hogy nem hoznak létre új jogot, csupán megtalálják azt, s amennyiben mégis megváltoztatnak egy korábbi döntést, az valójában csak azt jelenti, hogy a korábbi határozatban a bíró rosszul találta meg a már meglévő jogot.) $)^{15}$

Mindenesetre a skót jog „belső ereje”, függetlenségének záloga - a kimondott deklaratív hatalom mellett - magában a flexibilitásában rejlik. Ugyanakkor kijelenthető, hogy például az úgynevezett „béke megszegése” (breach of peace) büncselekményébe lényegében bármilyen cselekmény beletartozik, vagyis mindenféle rendszerezett norma, precíz és egzakt kategorizálás nélkül egyes cselekmények vádolhatóvá válnak. ${ }^{16} \mathrm{~S}$ mégis ennek ellenére nem lehet a skót büntetőjogról azt mondani, hogy teljesen megjósolhatatlan döntések születnének vagy a legalitás kifejezése teljesen értelmetlen lenne, noha az is igaz, hogy az univerzális terminusok helyett inkább a doktrínák, az eljárási garanciák, az intézményi hatalom és a tradíció kapcsolatára helyezi a hangsúlyt. S hogy ez mennyire így van: Lord Cooper 1949-es pamfletjének bevezetőjében a skót jogrendszer megkülönböztető jellegét a tradícióban látja, aminek eredete a skót nemzet történelmében rejlik.

$S$ ehhez még két dolog járult hozzá. Egyfelöl a skót jogrendszerre és természetesen a büntetőjogra is rendkívül jellemző „a nagyság hiánya”, vagyis más szavakkal relatíve kevés számú normából áll. Ennek egyenes következménye a rendszer, s különösen a büntetöjogrendszer extenzív fejlödése, hiszen mivel nincs kiterjedt fogalmi háló, nincsenek hivatkozható és továbbalakítható szabályok, így csupán a meglévő normarendszer újra- és újraismétlésére van lehetőség. Ennek nem mellesleg további következménye, hogy az egyébként új és új élethelyzetek, ha tetszik tényállások felmerülésekor a megoldás során inkább a praktikus és az informális utak kerültek előtérbe. Másfelöl - s ez már nyilvánvalóbb - Hume kommentárjai,

14 Uo.

15 Ne felejtsük el, hogy hasonló vita (a bírósági határozatok konstitutív vagy deklaratív ereje körüli vita) Angliában is lezajlott. Angliában is a deklaratív erő teóriája győzött, miszerint az új döntés - legyen az bármilyen módon (distinguishing, overruling) statute, szokás vagy a common sense alapján - felülírva, csupán azt jelenti, hogy az új bírói döntés helyesen találta meg a meglévő természetjogot. Lásd: FRANK, Jerome: Law and the Modern Mind. Garden City, New York, 1930.

16 FARMER: i. m. 
mint összegyüjtött és rendszerezett szabályok összessége, a legerösebb intézményi státuszt és referenciát biztosította a skót hagyományok számára. $S$ a fentiek pedig immáron egyértelműen biztosították a skót jogászság számára az oly sokat hangoztatott történelmi konzisztenciát.

Vagy ahogy ezt Lord Cooper megfogalmazta: „Büntetőjogunk hagyományai és zsenialitása ellen való lenne, ha azok elveit csupán légüres térben kezelnénk ... saját eredendő módszereink eredeti jogelveinkre történő alkalmazása biztosítja jogunk flexibilitását és elasztikusságát, hogy képesek legyünk megkülönböztetni az egyes ügyek ténykérdéseiből eredő bizonytalanságokat..."17 Azon túl, hogy az idézet megmutatja a skót jogászság szemléletét, ennél több kérdés vizsgálatára is ösztönöz.

1. A skót jog „érettségének” vizsgálatára, mely kérdés sem problémamentes önmagában. Egyrészt érvényesült az az - elsősorban angol - álláspont, miszerint a skót büntetőjog érettségét csak a XIX. században érte el, s Mackenzie romantikus megközelítése csupán a hosszú időn keresztüli angol jog kölcsönzését követte, egészen Hume szintéziséig. Másrészt érvényesült Hume - mellesleg anakronisztikusnak tekinthető - deklaratív elve, miszerint minden felelős ügyvéd Hume bíró állításait modernként aposztrofálja. $S$ végül egyfajta szintézisként kimondhatóvá vált, hogy a korai időszakokban limitált parlamenti jogalkotásból egyértelmüen következett a bírói jogalkotás körüli vita. Hiszen amennyiben a törvényhozói jogalkotás nem volt túlzottan aktív, addig a bíróságok döntéseikkel „pótolták” a hiányzó szabályaikat.

Minderre végül is Hume gyüjteménye adott iránymutatást: modern szemlélete a liberális és flexibilis elvekkel feloldotta a premodern rigiditást, ugyanakkor a bírói jogalkotásról folyó vita is feleslegessé vált, hiszen minden büncselekmény már jogelvek alapján lefedetté vált. Mindezzel párhuzamosan érvényesülhetett az a - ha tetszik evolucionista - jogelmélet, miszerint a sötét korokból (középkorból) a jogrendszer kivezetett a racionalizmusba és a civilizációba, noha ez természetes konfliktushoz vezet a tradicionalizmus és a társadalmi változások között. Ám Lord Cooper szavaival (1949-ben) az utóbbi 120 év alatt „jogunk inkább a dinamikus jelen, mint a történelmi múlt felé hajlott."18 Vagyis innentöl kezdve az analitikai pozitivizmus itt is előtérbe került és a ,jól bevett” historizmus, történeti iskola feleslegessé vált. Vagyis a skót büntetőjogi szemlélet és értelmezés az általános európai kontinentális attitủddel együtt - s ez most esetlegesen távoli asszociációnak tűnik - a társadalmi, $s$ ezzel párhuzamosan a politikai változásokkal együtt egyfajta „liberális” (whig) átalakuláson ment keresztül.

2. Egy további lehetséges vizsgálódási szempont, hogy egyfelöl megjelent az „,igazán” centralizált állam képe. Ez még önmagában nem lenne olyan különleges, hiszen ez máshol is megtörtént, ám itt mindezt Skócia és Anglia relációjában és

17 "It is contrary to the tradition and genius of our criminal law to deal with its basic conceptions in vacou ... By the application of our native methods to our native principles it has proved possible ... to keep the law sufficiently felxible and elastic to enable a just discrimination to be applied the ascertained facts of each case..." LoRd CoOper: Supplementary Memo to the Royal Comission on Capital Punishment (Evidence $18^{\text {th }}$ day, 4 April 1950. 428. 4. Paragraph.) S ez mennyire igaz: nyugodtan kimondható, hogy hiányzik mind a merev szabályhoz ragaszkodó, túl általános kontinentális jogrendszerből, s éppúgy hiányzik a common law rendkívüli precedenskötöttségéböl.

18 LORD COOPER: i. m., 179. 
adminisztratív rendszerének kapcsolatában kell értelmezni, s itt meghatározott szerepe lett a helyi autoritások (önkormányzatiság) autonómiájának. Ezen szempont másik oldalaként azonban a protestáns vallásnak a „bünről” felfogott szemlélete, illetve annak szerepe sem elhanyagolható. Harmadsorban pedig minden változtatás jogáganként egyfajta silószerü elkülönültséget fenntartva ment végbe, akár az eljárásjogok, akár meglepő módon az egyes büncselekmények között is. Ezzel lényegében „felrúgva” a hagyományok és a történelem által teremtett egységet, átadták helyüket a parlamenti, kormányzati és adminisztratív normaalkotásnak: vagyis hirtelen minden „új keletüvé” vált. ${ }^{19}$

3. A harmadik érdekes kérdés az Angliától való függetlenség kérdése, ami szintén nem újdonság, hiszen ez Skócia klánjait újra és újra áthatotta. Azonban ez a függetlenség nemcsak „karddal”, de például a jog által is kivívható. Bár ahogy Hume lamentálva mondja: „az a vágy, hogy a közösség iránti becsületünk miatt hazánk jogát utódaink számára megóvjuk, úgy tünik, reménytelenné vált". ${ }^{20}$ Emellett - attól függetlenül, hogy az Angliával való politikai egység mellett „természetesen” kiállt, folytonosan hangoztatta a skót jogrendszer szeparációjának előnyeit, az angliai „liberális, felvilágosult, romlott emberekkel szemben”, ahol az angol bíróságok „megmételyeződtek a korrupció által". ${ }^{21}$ (Vagy csak egyszerüen inkább praktikusabbak voltak?) Ez az előny Skóciában elsősorban a tapasztalat bizonyítékán alapul, ellentétben a sok esetben a történeti tényállások valós bekövetkezte előtti megtévesztő emberi találgatás (common sense) bölcsességével; s így az igazi skót common law jogi gondolkodásmód különb az angol common law-tól. ${ }^{22}$ (Valójában a különbséget abban látták, hogy az angol bírói jog fikciói az eljárásjogból „csepegtek le”, ezért rengeteg olyan eljárási „bravúrt” kellett végrehajtani, ami megoldást kínált a valós, anyagi jogi tényállásokra, ezzel ellentétben a skót esetjog a tényleges történeti problémák megoldására törekedett, vagyis - ha tetszik - anyagi jogi jellegủ volt.) Mellesleg az angol common law is - noha két évvel késöbb - eljutott a skótéval többé-kevésbé azonos következtetésre: 1991-ben a Lordok Háza elutasította egy férj fellebbezését, amit a férfi a feleségével szembeni nemi erőszak kísérletéért kirótt büntetés miatt nyújtott be, és az ítélet érvelése is hasonló volt. ${ }^{23}$ Ebböl pedig több dolog következik: egyfelöl az Egyesült Királyság esetjogára a „tagállamok” bíróságai (sőt még akár az Egyesült Államok tagállami bíróságai is) igenis figyelemmel vannak; másfelöl talán nem is annyira "merev” az angol esetjog; harmadrészt a kérdés talán bonyolultabb, mint azt a skót jogászi közvélemény látja.

19 FARMER: i. m., 32.

20 Nelken, David: Criminal Law and Criminal Justice: Some Notes on Their Interrelation. In: Dennis, lan (ed.): Criminal Law and Justice. London, Sweet and Maxwell, 1987, 3-4.

21 Uo., 4.

22 Vagyis az angol common law csalóka fikciók tömege; egyébként az esetjog általában „hemzseg” a fikcióktól, s nem kizárt, hogy ezek egy része ténylegesen „csalóka.” Uo., 13.

23 1736-ban Sir Matthew Hale bíró ítélete szerint a férj „nem itélhető el törvényes feleségével szemben elkövetett nemi erőszak miatt, hiszen a házasságba való közös beleegyezésük, és a házassági szerződés alapján a feleség e téren alávetette magát férjének, és ezt utólag vissza nem vonhatja”. S 1991 októberében a Lordok Háza, Lord Keith szavai alapján kimondta, hogy „Sir Matthew Hale itélete a kihirdetés korának megfelelő helyzetet tükrözi... Modern korunkban minden ép érzékkel megáldott egyénnek el kell utasítania ezt a vélekedést." Vö.: Giddens, Anthony: Szociológia. Osiris Kiadó, Budapest, 2000, 201. 
4. A skót bírói jog szintén szembeállt nemcsak az angol, de a skót parlament által hozott szabályozásokkal is; ennek volt eredménye például az úgynevezett Fekete Könyv (Black Acts), a skót büntetöjogi törvénykönyv, melyet meglehetős antipátiával fogadtak a skót jogászi körök. Következésképpen a skót jogásztársadalom inkább az - akár skót, akár angol - common law-t is figyelembe vette müködése során, mert ezt eredményesebbnek és jogi szempontból igazolhatóbbnak találta. S mindezt alátámasztotta a deklarációs elv érvényesülése: hiszen a bírák csupán megtalálják a helyes jogot, szokást, s számukra nem kell elöírni a „törvényt”. Különösen igaz ez, ha az adott jogi norma nem is Skóciából származott: több esetben is a skót bíróságok gyakorlatilag figyelmen kívül hagyták az angol törvényeket (statutes), s ezzel végső soron megtiltották azok alkalmazását. (Érdekességképpen megjegyezhető, hogy a Brit-szigetek bíróságai eleve nem túl konformak a törvényhozással, ${ }^{24}$ s elképzelhetö, hogy hogyan gondolkodnak egy olyan törvényröl, amit még nem is saját nemzetük törvényhozási testülete hozott.) Vagyis kétségtelenül az „egyesült királyságok" közötti nemzeti identitás jogi kifejezésmódjának egyik eklatáns példájáról beszélhetünk. ${ }^{25}$

Természetesen a történet ebben az esetben sem ilyen egyszerü: Hume végső soron egyfajta common law-t részesített elönyben, de elutasította az angol esetjogot és jogalkotást, ám mégis figyelembe veendőnek tartotta azt, sőt a római jogot is, amennyiben a megváltozott társadalmi viszonyokra (,a nemzet szemléletének megváltozása miatt", Viscount Stair) nem található eredendő skót szabály. ${ }^{26}$ Sőt Hume többek között - az angol barrister-barrister csatára jellemző eljárással szemben - a skót eljárásjog előnyeit is méltatta; miszerint a közvádló (Lord Advocate) intézménye az egész társadalom igazságérzetének záloga. Mindez pedig ugyan a szokásokhoz köthető, ám a saját, vagyis a skót szokásokhoz, melyek - nem mellesleg az angol király befolyásának ellenében - örök érvényűnek tekinthetők. Ám például a skót jogászi közvéleményben még tovább élt Sir George Mackenzie álláspontja, miszerint a jog elsődleges forrása a törvényhozás által hozott szabály (statute), s amennyiben a jogalkotás nem reagál egy adott társadalmi problémára, a római jog követendő: „semmi sem lehet büncselekmény, amíg az egy törvény által nem minősül annak, $s$ innentöl kezdve a tények nem minősülhetnek másképp, és nem kerülhető el a bírói út". ${ }^{27}$

A fentiek eredményeképpen - az egyébként is meglévő kontinentális kulturális kapcsolatok miatt - a skót jogászi közvélemény inkább a kontinentális jog felé fordult, ha nem is konkrét szabályozásokban, de szellemiségében mindenképpen. Egy olyan racionális jogelvi rendszert adaptáltak, mely már az európai kontinens számá-

24 Lásd Pokol Béla: A jog szerkezete. Rejtjel Kiadó, Budapest, 2000.

25 FARMER: i. m., 33.

26 Uo., 36.

27 „I were to be wished that nothing were a crime which is not to be declared so, by a statute, for this would make subjects inexuseable, and prevent the arbitrariness of judges." MACKENZIE, Sir George: The Laws and Customs of Scotland in Matters Criminal, wherein it is to be seen how the Civil Law, and the Laws and Customs of other Nations do agree with and supply ours. Stair Society. Vol. 59. Edited by Olivia F. Robinson. University of Glasgow, Edinburgh, 2012. 
ra ismeretes volt, ${ }^{28}$ ellenben a - skót jogászság szerint - merev és „szűk látókörü” angol jogrendszerrel. ${ }^{29}$ Ezt szervezeti szempontból is alátámasztotta a Lordok Házától való szeparáció, s emellett még mindig - bizonyos tekintetben és mértékben, a társadalmi változásokkal összhangban - elfogadták a skót törvényhozás döntéseit. Ettől függetlenül - amennyiben ez lehetséges volt - a precedensek tekintetében a skót bíróságok döntéseit preferálták, s az angol határozatokat csupán végső esetben használták fel. S ennek igazolására természetesen nem a nemzeti identitást használták fel (ez túl feltűnő lett volna), hanem azt az érvelést, miszerint a skót jog és a skót büntetőjog - noha esetjellegü - a kollektív bölcsesség forrásából eredeztethető, ellentétben az angol common law-val, melynek fejlődése kizárólag esetről esetre történhet. S ha például a hasonló precedensek „vonala” eltért a bíróság által elképzelt döntéstől, akkor egyszerüen Hume normagyűjteményével igazolták azokat. Ugyanakkor Hume autoritásának megkérdőjelezhetetlensége mellett, még tőle is eltérhettek: amennyiben Hume szabálygyűjteménye nem adott iránymutatást, vagy nem volt megfelelő a norma, netán abszurd döntési eredményre vezetett volna, egyszerüen egy korábbi precedenssel igazoltak egy egyébként a jelenkor viszonyainak megfelelő döntést. Vagyis ez egyfajta „többes” játékot jelentett: a bírói döntést igazolták, Hume autoritása intakt maradt, a döntések sorozatai mégsem váltak inkonzisztenssé, ám a határozatok praktikus okai biztosítottak maradtak, s ráadásul a tradíció által biztosított belső kohézió is megmaradt. Ahogy ezt Lord Cooper megfogalmazta, a jogtudomány sokkal inkább a praktikusok munkáján nyugszik, mintsem a jogalkotáson, vagy az akadémikusokén. Aki mégis az absztrakt teóriákat preferálja, annak az „eredendő értelemre” (native genius) kell hagyatkoznia, vagyis ismét visszatértünk Hume-hoz. Akinek munkái „szórakoztatóak, zseniálisak, lenyűgözőek és érdekesek", minden büntettel és büntetéssel kapcsolatban megadja azok filozófiai bázisát, ám az egyes esetek eldöntésének tekintetében már nem feltétlenül tud releváns bázist adni. ${ }^{30}$

A praxissal kapcsolatos fenti felfogás elvezetett ahhoz a XIX. századi folyamathoz, mely lényegében Hume büntetőjogi munkájának leegyszerüsítéséhez vezetett. Bár ennek oka nemcsak a praxissal kapcsolatos vélemény volt, hanem a praxis igénye is az egyszerübb és így könnyebben és gyorsabban meghozható döntésekre, továbbá a joghallgatók is igényeltek egy könnyebben tanulható joganyagot. Mivel a jog és a jogi oktatás nagyon is összefüggő, szerves kapcsolatban áll egymással, ahogy Felix Frankfurter bíró fogalmazott: „amilyenek a jogászok, olyan a jog, s mind-

${ }^{28}$ SмIтH, Thomas Braun: A Short Commentary ont he Law of Scotland. W. Green and Son, Edinburgh, 1962, Chapter 5.

${ }^{29}$ Ennek bővebb ismertetésére lásd DAviD, René: A jelenkor nagy jogrendszerei. Összehasonlító jog. Közgazdasági és Jogi Könyvkiadó, Budapest, 1977. „A precedens-szabálynak csupán az a célja, hogy a hagyományoknak megfelelö, a bírói gyakorlaton alapuló struktúra megtartásával biztosítsa az angol jog kereteit." $S$ egy kritika René Davidtól: „A precedensszabály sem gördít több akadályt az angol jog fejlödése elé, mint amennyit múlt századbeli ellenzőinek sötét jóslatai ellenére a kodifikáció gördített az európai kontinens jogai elé." DAVID: i. m., 318. A kontinentális jog vonatkozásában Friedrich von Savigny véleménye pontosan egyezett az általános véleménnyel, s lám: a jogászi közvélemény bizonyos tekintetben tévedett, a változás - bármely jogrendszerben - lehetséges.

30 LORD COOPER: i. m.; FARMER: i. m., 35. (Bár ebböl a szempontból inkább közelített Blackstone Kommentárjaihoz, illetve az azzal kapcsolatos angol felfogáshoz.) 
kettőt a jogi oktatás alakitja". ${ }^{31}$ Mindez végül elvezetett a skót büntetöjogra rendkívüli hatással járó, s egyúttal rendkívül leegyszerüsített Macdonald által megalkotott Gyakorlati Tanulmányokhoz (Practical Treatise), melynek a büntetőjogra mért hatását már önmagában megmutatja, hogy 1867 és 1948 között öt kiadást ért meg. ${ }^{32}$ Mellesleg ez a munka, mely a bíróságokon általánosan használatban volt, felborította a bíróság és a törvényhozás közti egyensúlyt (balance of power).

\section{A késöbbi jogi fejlemények}

A fentiek eredménye egy olyan skót büntetőjogi rendszer, mely - az angol büntetőjogi gyakorlattal (precedensekkel) szemben - korábban előszeretettel alkalmazta a halálbüntetést, ám ugyanakkor rendkívüli módon „elnéző” volt. (Ti. az angol rendszer nem alkalmazott súlyos büntetéseket, kivéve az általában politikai okok miatt a Star Chamber elött megvádolt személyek esetében, ám kevéssé volt flexibilis, hiszen az angol common law rendkívüli merevsége köztudott. ${ }^{33}$ ) Vagyis vagy az adott cselekményt nem tekintették „tényállásszerünek”, vagy eltekintettek a szigorúbb büntetéstől, esetleg előnyben részesítették a „kegyelem intézményét”. Ám ennek politikai okai is voltak, hiszen a Lord Advocate a politikai igények kielégítésének zálogaként is müködött. Konkrétabban: a Tory párt által vezetett Dundas kormányzat alatt, amikor is a skót társadalomban radikálisabb, az önállóságot erősebben hirdető politikai irányzatok jelentek meg, az egyébként a súlyosabb büntetéseket nem alkalmazó büntetőgyakorlat, mint Damoklész kardja, bármikor szigorúbbá válhatott.

Azonban ugyanebben az időben jelentkeztek a kontinensen elsősorban a Cesare Beccaria nevével fémjelzett ${ }^{34}$ büntetőjogi reformok, melyek megegyeztek a skót társadalom politikai igényeivel is. $S$ a politikai kérdések mellett, de azokkal párhuzamosan könnyedén vissza lehetett térni a - nem mellesleg a jogi önállóságot hangsúlyozó - Hume-hoz: a törvények legyenek szigorúak, ám biztosítsanak meglehetősen széles diszkréciót, hogy a bíróságok „bölcsességére” legyen bízva a megfelelő és helyes ítélet. Vagyis a büntetőpolitika könnyedén hivatkozhatott a nemzeti identitásra, mint „a skót jogrendszer örök bölcsességére” s ezzel párhuzamosan kitérhettek a társadalom reformigényei elöl is. Vagyis a jogalkalmazás szempontjából, amellett hogy kontinentális szemléletet hordozott - bármely oldalról is nézzük - az ügyfelek és jogaik a jogászok és bírák döntéseinek kezében maradtak. ${ }^{35}$

$S$ végül eljutottunk az igazán „modernnek” tekinthető jogi vitákig, melyek megtárgyalása már mindenképpen a jogszociológia tárgykörébe tartozik. Nevezetesen a helyes és helytelen cselekedetek és a közösség kapcsolatához, pontosabban, hogy a közösség megítélése milyen egy-egy cselekmény kapcsán. A fentiekben már

31 Letter from Frankfurter to a Mr. Rosenbaum (May 13, 1927). CARRIngton, Paul D.: Butterfly Effects: The Possibilities of Law Teaching in a Democracy. Duke Law Journal, vol. 41., 1992, 741-742.

32 Utolsó kiadása Athole, Macdonald-HaY, John: A Practical Treatise on the Criminal Law of Scotland. W. Patterson, Edinburgh, 1867.

33 Általánosságban lásd DAVID: i. m.

34 Lásd: BeccariA, Cesare: A bünökröl és a büntetésekröl. 1764.

35 FARMER: i. m., 38. 
említett deklaratív elvvel kapcsolatos diskurzus egy olyan irányt vett, miszerint a bíróságoknak igenis joguk van arra, hogy büntetést szabjanak ki minden olyan cselekményre, mely „különösen helytelen” (extraordinary wrong) vagy nyilvánvalóan helytelen (obviously wrong) vagy ugyan már régóta helytelennek tartott, ám elöre nem látható - nóvumként felmerülő - módon hajtották végre. Mindezzel összefüggésben felmerülhetnek olyan kérdések, minthogy mit tartanak „becstelennek”, jogelvekkel ellentétesnek, nem elvárhatónak, etc.; mely elsősorban a közösség megítélésén múlik, ám ez a közösség természetesen ebben az esetben a (skót) nemzetet jelenti. Azonban ez a nemzeti kollektív tudat is időröl időre változhat természetesen.

Végül is a bünös cselekmény fogalma elsösorban a közrend megsértésében, a kormányzat és a társadalom megvédésében teljesedett ki. Ezzel együtt egy olyan társadalmat aposztrofált, mely konfliktusmentes és ezzel párhuzamosan a jogalkotói mechanizmusoktól mentes. (Hiszen egy olyan társadalomban, ahol nincsenek konfliktusok, nincs szükség normákra sem.) Ám a valóság mást mutatott, következésképpen (törvényi normák hiányában) a jogi érvelés a kollektív bölcsességen alapult, $s$ az mégis az esetjogot jelentette. Intézményi szempontból pedig az esküdtszéki eljárást, mely intézmény olyan racionálisan gondolkodó emberekből áll, akik reprezentálják a közösséget; ${ }^{36} \mathrm{~s}$ a „racionális ember” kifejezés tökéletesen megadja azt a standardot, mely egyfajta tesztként használható. ${ }^{37} \mathrm{~S}$ most attól függetlenül, hogy ez mennyire objektív vagy szubjektív, egy így meghozott döntés - anélkül, hogy bármiféle univerzális absztrakt standardra, mint egyfajta külső mértékre lehetne hivatkozni - a közösséget reprezentálja. Így pedig - ellentétben az angol-amerikai jogszolgáltatással, mely elvekből dedukálható, s inkább etikai kérdésként fogható fel - a skót büntetöjogi döntések technikai kérdésként foghatók fel. Ennek eredményeképpen, párhuzamosan a nemzeti izolációval (ti. hogy nem figyelnek más common law országok esetjogára) a skót büntetőjog lényegében azt jelenti, amit az egyes ügyekben, az adott körülmények között a bíró kimond, ami végső soron ugyan a jogból vezethető le, ám úgy, ahogy a bíró azt a jogot a közösség felé interpretálja. Tehát a skót büntetőeljáráson belül egyetlen univerzálét találhatunk: a jog mindig egy meghatározott időben egy meghatározott közösséghez köthető, s paradox módon ez jelenti a skót jog kontingenciáját. ${ }^{38} \mathrm{~A}$ deklarációs elv által is megtámogatva, így a skót rendszer legalitásának nem lehet kapcsolata, mondjuk, mint a kontinensen, az alkotmánnyal, vagy mondjuk az Emberi Jogok Európai Egyezményével, hanem csak a bíróval, akinek az adott ügy, ügyek a kezében vannak. Vagy, ahogy ezt Günter Teubner megfogalmazta: a meta-teoretikus standardok soha nem válnak externális referenciáivá a skót jogrendszernek; ehelyett ezekre a standardokra úgy kell tekintenünk, mint a társadalmi realitások kifejeződéseire vagy a joggyakorlat olyan módozatára, mely kizárólagos önreferenciával bíró állandó körkörös mozgásban van. ${ }^{39}$

36 Uo., 39. Ahogy Sheriff Gordon fogalmazott a „hanyagság”, illetve „elvárhatóság” (recklessness) tekintetében, miszerint számunkra tökéletesen ismeretes, hogy a közösségnek a kérdéssel kapcsolatos ideái képezik a skót jog legitimációját.

37 Gordon, Sir Gerald: The Criminal Law of Sotland. W. Green and Son, Edinburgh, 1978, 244.

38 FARMER: i. m., 40.

39 TeUbner, Günter: „And God Laughed ...” Indeterminacy, Self-Reference and Paradox in Law. In: Joerges, Christian-Trubek, David M.: Critical Legal Thoght: An American-German Debate. Nomos Verlagsgesellschaft, Baden-Baden, 1989, 399-434, 406-409. 
Így a skót büntetőjog legitimációját a körkörösség és a bizonytalanság paradoxona adja. De mi a helyzet a társadalommal, illetve annak változásával?

\section{A jogi kérdésekkel párhuzamos társadalmi fejlemények}

Ami a bíróság által megnevezett „társadalmi változásokat” illeti: vajon mi történhetett, hogy a társadalmi attitűd a nevezett „esettel” kapcsolatban ilyen gyökeresen átalakult? Az persze teljesen nyilvánvaló, hogy a jogi döntés ugyan egyszeri aktus, mely egy meghatározott időpontban történt, a szociális szemlélet valójában sokkal hosszabb folyamat eredménye. Elég csak - már csak az esettel is összefüggésben - arra gondolni, hogy mind a középkorban, mind később az iparosodás korában is az otthoni környezetben az eröszak teljesen megszokott, úgymond „természetes” dolog volt. Sem jogszabály, sem a társadalmi szemlélet (például a kollektív erkölcsi elítélés) nem védte az erőszakot elszenvedőket, ez alól legfeljebb rendkívül súlyos sérülés vagy a halál okozott kivételt, az úgynevezett mentális, „lelki” következmények pedig fel sem merültek értékelési szempontként.

Természetesen nyilvánvaló, hogy a nők társadalmi státusza korábban (mondjuk Hume korában) sokkal alacsonyabb volt, aminek eredménye, hogy férjük (s emellett általában a férfiak) dominanciája érvényesült. Ám a helyzet megváltozott, méghozzá gyökeresen, de a kérdés még attól fennáll: vajon a társadalmi státusz változása magával hozhatta a szemléletváltozást is? Nos, a válasz - legalábbis többé-kevésbé - igen, méghozzá Pierre Bourdieu adta meg a választ, az úgynevezett szimbolikus tőke fogalmával. De a kérdés ennél komplikáltabb: társadalmunk tagjai többféle általa "tőkéknek" nevezett értéket hordozhatnak; mint például természetesen a „pénztőke”, a társadalmi kapcsolatokat magában hordozó „kapcsolati tőke” vagy a társadalmi státusszal járó „szimbolikus tőke”. S ezek a tőkék szoros korrelációban vannak egymással, vagyis egyik általában együtt jár a másikkal, a harmadikkal etc.; $s$ mindez persze igaz lehet társadalmi csoportokra is, jelen esetben a nőkre.

$S$ itt még egy kérdést fel kell vetni: a társadalmi státusz és a presztízs kapcsolatát, ami mint egy titokzatos erő, egyfajta tekintély biztosítja minden társadalmi réteg helyzetét, az elittöl a legalsóbb rétegekig. ${ }^{40} \mathrm{De}$ mi biztosítja bizonyos emberek számára a presztízst? C. Wright Mills után kimondható, hogy „a presztízshez nem elég a fegyverek vagy a pénz ereje (...) A hatalomnak bizonyos fokú hírnévvel kell párosulnia, hogy eredményeképpen presztízs születhessék." ${ }^{\text {"11 }}$ De a hírnév sem elég önmagában; természetesen szükség lehet az előzőekre, de további jelenségekre is. Azok a szociális magatartások, amelyeken annak idején Thorstein Veblen a presztízzsel kapcsolatban teoretizált, valójában „társadalmi állapotból eredő magatartások", vagyis olyan helyszínek fenntartása, létrehozása, mely a hasonló rétegek kö-

40 „Akármiféle uralmat is találtunk is a világon, akár eszmét, akár embereket, ezek nagyobbrészt azon ellenállhatatlan erő segítségével gyakorolják hatalmukat, amelynek neve presztízs (...) Ez az uralom paralizálja kritikai képességüket és csodálattal és tisztelettel tölt el..." LE Bon, Gustave: The Crowd. Ernst Benn, London, 1952, 129-131.

41 Milts, C. Wright: Az uralkodó elit. Budapest, 1962, 97. 
zötti együttmüködés biztosításának módjait segíti elö. ${ }^{42} \mathrm{~A}$ gondolatmenetet folytatva, Mills szerint Veblen „nem vette elég komolyan a társadalmi pozíció kérdését, mert nem látta meg annak teljes és bonyolult jelentőségét... s nem tudta felmérni a presztízs igazi súlyát." ${ }^{\prime 3}$

Vagyis a presztízs, hírnév megszerzéséhez a kulcs a pozíció, mely meghatározhatja a szimbolikus tőkét, ami identifikálja az adott társadalmi csoporttal kapcsolatos megnyilvánulásokat, szemléletet, melyek kialakulásával együtt járnak olyan kommunikációs terek, melyek az azonos rétegek, csoportok közti szolidaritás biztosításán túl különféle normák és szokások kialakítását is eredményezik, s ezen túl megkülönböztetésül is szolgálnak más csoportoktól. Márpedig a „kommunikációs terek” megváltoztak. De még mielőtt túlzottan „elöreszaladnánk”, érdemes „egy pillantást” vetni a társadalmiság és a kommunikáció kapcsolatára.

A kérdés történelmi perspektívája a XIX. század végére, illetve a XX. század elejére nyúlik vissza, amikor is a nőket egyre inkább bevonták a termelő tevékenységbe. (Ne feledjük, hogy a "háztartási munka" is termelés, csupán a társadalom szemléletében nem tekinthető annak.) A korábbi családi gazdálkodást felváltotta az ipari termelés, amiben szükség volt további munkaerőre, mivel a társadalom egyik fele számszerüen elégtelennek bizonyult (manapság a nők országtól függően persze 35-60\%-ban munkaviszonyban állnak) ${ }^{44}$ melynek oka elsősorban a munkahelyek számának megnövekedése. Ugyanakkor nem szabad megfeledkezni a két világháborúról és más háborúkról, ami miatt oly mértékủ munkaerőhiány lépett fel, hogy a nőket nagyobb számban is bevonták a munkaerőpiacra. Ezzel összefüggésben már ténylegesen megemelkedett társadalmi presztízsük, amit többek között a politikai részvételi jog is megmutatott, hiszen - egyébként a legtöbb országban a második világháború után a '40-es, '50-es években - elismerték a nők szavazati jogát. ${ }^{45}$

Ám a munkaviszonyban való, a nőket érintő megkülönböztetés továbbra is fennállt, illetve fennáll: ennek egyik nyilvánvaló példája, hogy az állásvállalás során rendszeresen felmerül a gyermekek számának vagy a gyermekvállalásnak a kérdése. Ugyanakkor ez az egyébként kifejezetten negatív megkülönböztetés egy másik látens negatív megkülönböztetéssel is jár, nevezetesen azzal, hogy a nőket tekintik a családról és a gyermekekröl való egyedüli „gondoskodónak”, a férfiak - minden munkaviszonybeli pozicionális előnyük ellenére - társadalmi szerepe, illetve az azzal kapcsolatos attitüd degradálódott. ${ }^{46}$

42 Milts: i. m., 99

43 Uo., 100.

44 S csupán külön a jogásztársadalmat érintő érdekesség: korábban az angol felsőbíróság (High Court; azelőtt Queen's Bench) bírói között 3\% volt a női bírák aránya és mind a harmadik kamarában (Family Division) bíráskodtak, a „legfelsőbb bíróság” (Lord of Appeal) tagjai között egyetlen női bíró sem volt. A '90-es évek elején viszont az angliai joghallgatók fele, manapság pedig már több mint a fele nő. GIDDENs: i. m., 191.

45 Elsőként ugyan 1893-ban Új-Zélandon ismerték el a nők szavazati jogát, majd Ausztrália és többnyire a skandináv államok következtek, 1917-ben Szovjet-Oroszország, 1920-ban az Egyesült Államok, a két háború között néhány európai ország, köztük Nagy-Britannia (1928), ám a legtöbb ország a háború utáni egy évtizedben; utolsókként pedig Peru és Zimbabwe 1979-ben. TutTLE, Lisa: Encyclopedia of Feminism. Longman, London, 1986, 370-371.

46 Ahogy egy vállalatigazgató a gyermekvállalásról ezt megjegyezte: „Elismerem, hogy ez egy kicsit személyeskedő kérdés, de azt hiszem, egy olyan mozzanatról van szó, amit figyelembe kell venni. Ráadásul ez 
Mindezzel párhuzamosan, illetve a háború utáni szociális szituációt is szemlélve megjelent még egy „újdonság”: nevezetesen, a nők bevonása a társadalmiságba. ${ }^{47}$ Ez az elöbbiekből is következően erősen kapcsolódik a munkaviszonyokhoz, de önmagában is érdekes kérdés, hiszen involválódtak egy olyan kommunikációs közegbe, amiben korábban nem volt részük.

S a kommunikáció, Talcott Parsons elméleteitől kezdve Niklas Luhmann szintéziséig „lehet a társadalmiság alapeleme is”, és a szociális viszonyok kialakulásában mindenképpen az egyik legfontosabb szerepet játssza. Ahogy Pokol Béla Luhmann értelmezéséből is kiolvasható: „az ilyen szerkezetű kommunikáció konstituálja a szocialitást, és ez már a pszichikai rendszerek cselekvéséből (azok koordinált értelmi összhangjából) áll..."48

Márpedig a kommunikáció hatását nemcsak hogy nem szabad alábecsülni, de elsődlegesen meghatározhatja a társadalmi vonulatokat is; vagy, ahogy ezt Niels Christie plasztikusan megfogalmazta: „szökőkútnál, kútnál vagy más természetes folyó menti találkozóhelyen gyülekező nők... Vizet hordanak, ruhát mosnak, és információkat, véleményeket cserélnek. Beszélgetésük kiindulópontja gyakran a konkrét cselekmény és szituáció lesz. Ezeket jellemzik, összehasonlítják múltbeli vagy máshol elöforduló hasonló történésekkel, és kiértékelik őket - jó vagy rossz, szép vagy csúnya, erős vagy gyenge. Lassan, de korántsem minden alkalommal, valamilyen közös értelme alakulhat ki a hasonló történéseknek. Ez az a folyamat, amelynek során a normák létrejönnek. Ez egy klasszikus esete az egyenlöségre törekvő igazságnak.

...A kút megszünt. A modernizált országokban egy ideig érmével müködő mosószalonok müködtek, ahová betérhettünk a koszos ruhákkal, és a tisztákkal távozhattunk. A köztes időben pedig ráértünk beszélgetni. Napjainkra már az ilyen mosószalonok is megszüntek..."49

Ez nyilván a fenti szociális szituációt értelmezve még face to face társadalmakat jelentett és a társadalom szerveződése az interakciós rendszereken belül történt, ám az utóbbi évtizedekben az interakciók tömege jelent meg, és a társadalom ezek közötti ellentmondások mellett is tudta biztosítani stabilitását. S mindezt persze elö-

egy olyan dolog, ami a férfiakkal nem fordulhat elö. Lehet, hogy ez bizonyos mértékig igazságtalan. Itt nincsenek egyenlő esélyek, hiszen a férfinak nem lesz ilyen értelemben családja." GIDDENs: i. m., 191. Tehát a társadalom egyik része értéktelenebb a munkaviszonyban, a másik része pedig a kapcsolati viszonyokban: vagyis az egyik nyilvánvaló megkülönböztetés magával hozza a másikat.

47 Ennek (ti. a nők bevonása a társadalmiságba) hiányáról lásd DuRKHEIM, Emile: Az öngyilkosság. Közgazdasági és Jogi Könyvkiadó, Budapest, 1967.

48 Részletesebben lásd Poкоц Béla: $A$ professzionális intézményrendszerek elmélete. Felsőoktatási Koordinációs Iroda, Budapest, 1991, 17-22.

49 „Mózes lejött a hegyröl. A hóna alatt hozta a törvényeket, gránitba vésve, melyeket még a hegyeknél is magasabban lévő valaki diktált le neki. Mózes csak egy hírvivő volt, az emberek - a nép - voltak a befogadók... Jóval később Jézus és Mohamed ugyanezen elvek szerint cselekedett. Ezek a piramisszerü igazság klasszikus esetei... Egy másik kép: szökőkútnál, kútnál vagy más természetes folyó menti találkozóhelyen gyülekezö nők (...) Hatalmas bevásárlóközpontokban lehetőség van a találkozásokra, de ezek általában túl nagyok ahhoz, hogy alkalmasak lennének horizontális igazság létrehozására. Túl nagyok ahhoz, hogy megtaláljuk régi ismerőseinket, túl forgalmasak és zsúfoltak ahhoz, hogy hosszúra nyúlt beszélgetéseket folytathassunk, amelyek során viselkedési normákat állítunk fel..." CHRISTIE, Niels: Civility and State. (kézirat). In: Bauman, Zygmunt: Globalizáció. A társadalmi következmények. Szukits Könyvkiadó, Kaposvár, 2002, 48-49. 
segítette a tömegkommunikáció, a hírek tömeges és viszonylag gyors átvitele, megismertetése. Ez a kommunikációs stratégia oly mértékben elterjedt, illetve behálózza társadalmunkat, hogy kizár szinte minden más (mellesleg létező dolgokról való) információt. ${ }^{50}$ Ezzel pedig - jelen esetben - egy társadalmi csoportot érintő vagy azok által támogatott normák is széles körben ismertté, mi több elismertté válhatnak. ${ }^{51}$

Végül így történhetett, hogy az elsőfokú bíró és a fellebbviteli bíróság bírája, Lord Mayfield, a keresetben feltett kérdést és a végső választ is Hume-ra alapozta, vagyis innentől kezdve autoritása megkérdőjelezhetetlenné vált. A jogi elv szerint pedig az, hogy a feleség „férjének megadta magát” mindig a konkrét eset fényében vizsgálható és nem lehet a „férj általános immunitására” hivatkozni. S mindez - ahogy a bíró hozzátette - nem egy új jogi irány (a new class of action) kreálásával történt, hanem egyszerüen egy meglévő jogelv alkalmazására került sor, miszerint a „férjnek nincs a váddal szemben immunitása"52 Mellesleg a döntés több helyen kiemelte a skót jog elsődlegességét, továbbá azt is, hogy „az angol jog bárminemü változása nem a bíróságon, hanem a Parlament beavatkozásán múlott". ${ }^{53}$

Ugyanakkor Hume autoritása, illetve a common law merevsége Skóciában nem jelentett abszolút és megkérdőjelezhetetlen szabályt. Másképpen: amíg Angliában a törvényi jognak (statute law) kellett beavatkozni az utólag (társadalmi változások miatt) keletkezett joghézagba, ${ }^{54}$ addig ezt Skóciában a bíróság is megtehette egyszerü jogértelmezés útján. Mivel az - egyébként Angliában is jogforrásként használt - józan ész (common sense) felülírhatta az általános elvet: „a jog élő rendszerének mindig figyelemmel kell lennie a változó körülményekre annak érdekében, hogy igazolni tudjon bármilyen az általános szabályok alóli kivételt". ${ }^{55}$ Hume autoritásának intaktsága, mint általános princípium mellett csupán a társadalmi változások jogkövetése és egyúttal a változással való igazolása történt.

Vagy, ahogy a bírói döntés kimondja: „A huszadik század második felében a nők pozíciója, és különösen a házas nők státusza jogrendszerünkben drámai változásokon ment keresztül”. ${ }^{6}$ Továbbá: „a jog élő rendszerében mindig lehet találni az általános szabályok alól valamilyen kivételt. Manapság pedig már nem lehet komolyan fenntartani azt a felfogást, hogy egy házas nő minden ellenkezés nélkül, minden

50 Bauman: i. m.

51 A tömegkommunikáció társadalmi hatására lásd GIDDENS: i. m., 426-431.

52 A magyar jog esetében a „tényállásszerűség” lehetne a leginkább szinonim fogalom, vagyis Skóciában, jelen esetben nem lehet vádat emelni valakivel szemben, amennyiben az nem tényállásszerü (nem ütközik törvénybe vagy meghozott elmarasztaló precedensbe). A magyar jogban ez ugyan megtehető, csak egyébként elvileg nem hozható elmarasztaló ítélet (nullum crimen sine lege).

53 Giddens: i. m., 472-473, 102-105.

54 Erre a megállapításra egyébként remek példa az Egyesült Királyságban meghozott Esélyegyenlőségi törvény (Equal Oppurtunity Act), ami szerint a munkáltatónak azonos munkakörben azonos fizetési rátát kell alkalmazni. A munkáltatók pedig egyszerüen megváltoztatták a munkakörök elnevezését, így a munkabéreket is, és az ez elleni kereseteket az angliai bíróságok természetesen elutasították. Így 1975-ben az Európai Közösség szigorúbb irányelvet - az egyenlő bérezés elvét (Equal Pay Act) fogadott el, miszerint az egyenlő értékkel bíró munkáért egyenlő fizetség jár. Vagyis ténylegesen „kívülről” kellett beavatkozni a jogrendszer anomáliáiba.

55 Stallard v. Her Majesty's Advocate, $473 \mathrm{G}-\mathrm{H}$.

56 Stallard v. Her Majesty's Advocate, $473 \mathrm{~F}$. 
körülmények között köteles alávetni magát minden szexuális interakciónak". ${ }^{57}$ Mellesleg a bíróság - amellett, hogy fenntartotta az általános szabályt - lefektetett egy általános elvet, miszerint az ügy körülményeitöl függően a férj is vádolható erőszakos közösüléssel.

\begin{abstract}
In this essay I have attempted to show the Scottish tradition of criminal law and attitudes of legal profession and the whole Scottish society about the crimes trough one case. This criminal case was held before the Scottish criminal appeal court in 1989, where for the first time, a man could be guilty under the Scottish law of raping his wife while the couple lived together. This was a point that could show the flexibility of Scottish law while the English law was either unwilling or unable to make a change.

This case shows us that the judges in Scotland claim to represent the social attitudes through legal devices but this representation is not almost uncountable because the courts attempt to operate within the basically conservative traditions. Parallel of the above mentioned the courts try to use the alternative histories of law and the voices of practical lawyers, legal doctrines through the conflicting interpretations in order to make right decisions.
\end{abstract}

57 Stallard v. Her Majesty's Advocate, 473 G-H. 